\title{
Transferring and adapting XR design principles across the Pacific
}

\author{
Claudio Aguayo \\ claudio.aguayo@aut.ac.nz \\ Auckland University of Technology
}

Keywords: Mixed reality, design principles, transferability, activity theory, design-based research.

\begin{abstract}
The use of mixed reality (MR, also XR) as an educational approach and pedagogical strategy merging real world and digital affordances along an immersive learning continuum has been explored across educational settings and contexts (Liu et al., 2017; Maas \& Hughes, 2020). In a study examining purposeful educational design using free-choice and self-determined mobile learning in and outside of the classroom in the context of marine conservation education to enhance ecological literacy, an XR intervention was co-designed with primary students and partners and implemented at a marine education centre located adjacent to a marine reserve north of Auckland, in Aotearoa New Zealand (Eames \& Aguayo, 2019). The design, development, and implementation of the XR intervention followed design principles and guidelines for the development of XR learning, grouped under four main areas: marine science and conservation (the context); development of ecological literacy; teaching and learning considerations; and mobile learning opportunities (the technology) (Aguayo et al., 2020). The XR intervention was named 'Pipi's World', and included a set of analog and digital elements, resources and learning opportunities themed around Pipi the snapper, a young female character who could show users her world, and the positive impacts of marine conservation. Pipi's World intervention included an augmented reality (AR) app, QR codes triggering 360 virtual reality (VR) videos, a high-end CGI (computergenerated interface) underwater VR adventure, a series of non-digital haptic experiences themed under a kelp forest (Smith, 2018), and a snorkel tour in the marine reserve. Evidence from this study indicates that the XR intervention had educational impact, by assisting some knowledge and attitude development on learners towards marine ecological literacy during and post-intervention (Eames \& Aguayo, 2020).
\end{abstract}

The framework that informed Pipi's World study was transferred, adapted, and tested during 2020-2021 in a similar marine conservation education context in Las Cruces, in central Chile. The local context presented similarities with Pipi's world in that both projects were based within a marine education centre situated next to a marine research station and marine reserve, with educational programmes tailored to meet the local national curriculum for primary and secondary learners, in addition to learning activities for visitors from the public. From the outset the framework developed by Aguayo et al. (2020) contained design principles that are generic in many ways but flexible and adaptable enough to be locally developed, according to the specific characteristics and conditions of each educational context. Following socio-ethnographic and socio-cultural activity theory considerations and strategies (Aguayo, 2016; Engeström, 1987; Leadbetter, 2005), framed on a design-based research methodology (Amiel \& Reeves, 2008), the grounding of the framework in the Chilean context consisted of examining the viability and adaptability of the framework's components within the local context (e.g. defining local topics of interests in marine conservation). This process was carried out with a local panel of experts, both online and over several visits to the target location, resulting in the XR intervention 'Explora Chile Es Mar' (explore Chile's ocean) containing a range of real and virtual affordances addressing Chile's marine conservation priorities, launched in June 2021. This presentation reports on the process and key aspects leading to the development of the XR intervention Explora Chile es Mar, with emphasis on the transferability and adaptability of the original framework into the Chilean context, including some comparison between both case studies, and implications and recommendations for future research and practice.

\section{References}




\section{SCHOLARSHIP OF TECHNOLOGY ENHANCED LEARNING}

SoTEL Symposium 16-18 February 2022

Aguayo, C. (2016). Activity theory and community education for sustainability: When systems meet reality. In D. Gedera \& J. Williams (Eds.), Activity theory in education: Research and practice (pp. 139-151). Rotterdam: Sense.

Aguayo, C., Eames, C., \& Cochrane, T. (2020). A Framework for Mixed Reality Free-Choice, Self-Determined Learning. Research in Learning Technology, 28: 2347. http://dx.doi.org/10.25304/rlt.v28.2347

Amiel, T., \& Reeves, T. C. (2008). Design-based research and educational technology: Rethinking technology and the research agenda. Educational Technology \& Society, 11(4), 29-40. https://www.jstor.org/stable/jeductechsoci.11.4.29

Eames, C. \& Aguayo, C. (2019) Designing mobile learning with education outside the classroom to enhance marine ecological literacy, Teaching and Learning Research Initiative, Wellington, pp. 1-20 [online] Available at: http://www.tlri.org.nz/tlri-research/research-completed/cross-sector/using-mobile-learningfree-choice-educational-settings

Eames, C., \& Aguayo, C. (2020). Education outside the classroom: Reinforcing learning from the visit using mixed reality. Set: Research Information for Teachers, (2). https://doi.org/10.18296/set.0173

Engeström, Y. (1987). Learning by expanding: An activity-theoretical approach to developmental research. Helsinki, Finland: Orienta-Konsultit.

Leadbetter, J. (2005). Activity theory as a conceptual framework and analytical tool within the practice of educational psychology. Educational \& Child Psychology, 22(1), 18-28.

Liu, D., Dede, C., Huang, R., \& Richards, J. (Eds.) (2017). Virtual, Augmented, and Mixed Realities in Education. Springer.

Maas, M. J., \& Hughes, J. M. (2020). Virtual, augmented and mixed reality in K-12 education: a review of the literature. Technology, Pedagogy and Education, 29(2), 231-249. https://doi.org/10.1080/1475939X.2020.1737210

Smith, J. (2018). Kō Rimurimu 'To Be Covered in Seaweed': Sensory Knowing, Holistic Understanding, and Meaningful Encounters Within a Marine Science Centre. Auckland University of Technology. Available at: http://hdl.handle.net/10292/11734

Thompson, J. (2002). Community education and neighbourhood (Vol. 1). Nottingham, UK: NIACE. 